\title{
関門海峡における風速・視程の出現頻度および 衝突海難に及ぼす影響
}

\author{
神鳥昭* \\ Distribution of Wind Velocity and Visibility as the Bases of Evaluating \\ the Frequency of Sea Collision in the Kanmon Strait
}

Akira KANDORI

\begin{abstract}
The sea collision generally occurs as the results of complicated interaction of the natural and human factors, the representatives of the former being the topography, oceanographic and meteorological conditions, and those of the latter being the conditions of navigators in connection with the ship's performance.

The collision in the Kanmon Strait apt to occur under strong wind and restricted visibility. For the purpose of safety traffic management, it is necessary to represent numerically the actual states of wind, visibility, and their relation to the frequency of sea collision therein, for only insufficient information were avairable in spite of the cardinal importance of this strait for marine traffic.

In the present report, the following two formulae for evaluating the frequency of sea collision in the Kanmon Strait under respective conditions were proposed, basing on the fomulae showing the distribution of wind velocity and visibility estimated from the records offered by maritime and meteorological authorities concerned.
\end{abstract}

1) For wind velocity

$$
p_{C}\left[V_{W}\right]=\sin ^{2}\left\{3.38-2.19 \sqrt{V_{W}+1}+0.40\left(V_{W}+1\right)\right\}
$$

where $p c\left[V_{W}\right]=$ collision probability in the wind velocity

$V_{W}=$ wind velocity in meter per second

2) For visibility

$$
p_{C}\left[D_{V}\right]=\sin ^{2}\left(1.31 D_{V}^{-0.30}\right)
$$

where $p C\left[D_{V}\right]=$ collision probability in the visible distance

$D_{V}=$ visible distance in kilometer

\section{1.はじめに}

強風や霧などの自然現象による海上交通障害については経験的によく知られているが，計量的な評価となると まだ十分とはいえない。しかし，直接の船舶運航は勿論のこと，長期にわたる港湾・航路の改善工事やこれに伴 ら船舶交通の安全確保, および将来の海上交通の安全管理等の計画・策定には, その地方における気象の特性と それらの安全運航への阻害度について定量的な知見が必要である。一方，風や霧などの出現傾向には地域的な特 性があり，数年間の気㢳観測資料を解析すればその地方の平均的な傾向を知ることができる。また，気象観測資

* 正会員 水産大学校（下関市吉見永田本町 1944） 
料に船舶交通社よび海難の調查資料を対応させて総合的に解析すれば気象条件別の海難事故率が推定でき, 安全 運航への阻害度についても巨視的観点から具体的な評価ができるものと思われる。

この研究では気象観測・船船交通調査および海難調查の諸資料を分析して, 関門海陕における風速と視程の出現 傾向を数学モデルで表現し，その特性について考察した。また，風速や視程が衝突海難に及ぼす影響を具体的に 判断するため, 風速・視程と通航船の衝突事故率との相関について回㷌方程式を導き, 定量的な評価を試みた。

\section{2. 資料および解析の方法}

対象とした関門海陕の区域は海峡東口の部埼燈台を中心とした 2.5 浬圏，西口の本州側黒埼と藍ノ島南端を結 ぶ線, 藍ノ島南端と九州側新日鉄戸畑工場用地北東端を結ぶ線および陸岸により囲まれた水域である。また，解 析に使用した資料は 1962, '66, '69 年の下関地方気象台地上気象観測日原簿（毎日 3 時閒ごとの観測記録で風 速・視程の資料数法各 8,760，霧については特に 1962 ’69 年の 8 年間の全資料を用い資料数は 147 である), 1963, '66, '67, '68 年に延 18 日間にわたって実施した関門海峡通航船舶寄態調查報告書(1)(2)(8)(4)（調查封象船 16,350 隻) および 1962 年から '69 年までの 8 年間の海䧼調查票（不要救助海難を含む衝突事故船 302 隻）であ る。

これらの資料を解析の対象ごとに分析して，風速・視程おうび通航船の衝突事故率に関する諸現象に数学モデ ルをあてはめた。な䄧, 得られたモデル式の適合度の判定指標として, 相関指数 $(\rho)$ および標準偏差 $(\sigma \mathrm{E})$ を求 めた。

\section{3. 結 果と考 察}

\section{1 風速の出現頻度}

観測資料についてビューフォート風力階級別出現嚬度をそれぞれの階級の風速中央值に対して示すと Fig. 1 のとおりである。風速の出現頻度のモードは階級 3 のところにあり，出現率 $29.35 \%$ である。また，階級 8 以 上の風の出現することはきわめて稀で，その出現率は $1.01 \%$ にすぎない。これらの観測結果に基づいて風速 $V_{W}(\mathrm{~m} / \mathrm{s})$ とその出現率 $p\left[V_{W}\right](\%)$ との関倸を数学モデルで表現すると次の式 (1) で表わされる $(\rho=0.9894$, $\left.\sigma_{\mathrm{E}}=1.71\right)$.

ただし，

$$
p\left[V_{W}\right]=0.22 \exp \left(4.92 \checkmark \overline{V_{W}}-1.21 V_{W}\right)
$$

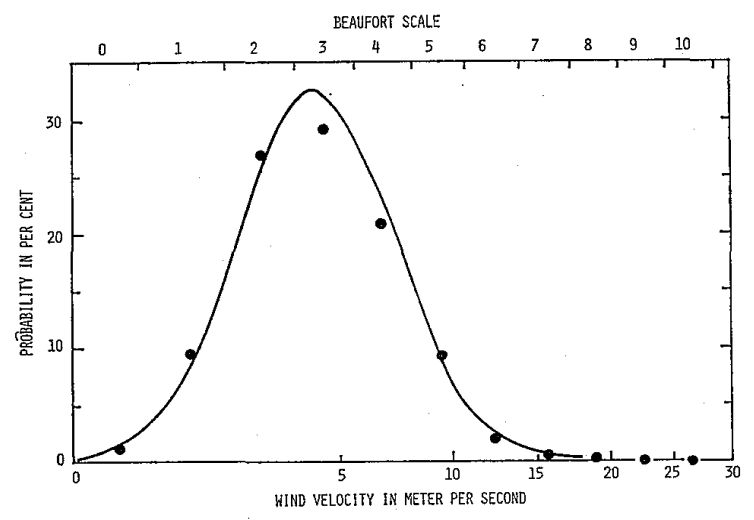

Fig. 1 Frequency distribution of wind velocity. Note; The wind velocity in meter per second is scaled in the square root values.

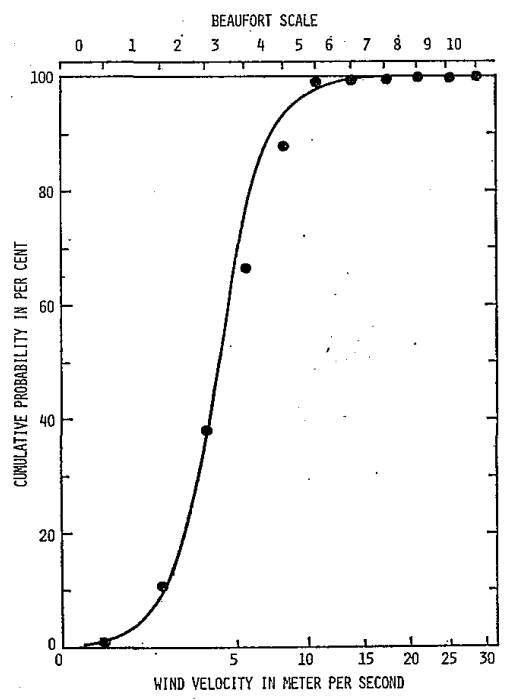

Fig. 2 Cumulative frequency of wind velocity. Note; The wind velocity in meter per second is scaled in the square root values. 
式 (1) から任意風速 (風力階級) の出現率を推測することができる。また, 関門海峡における最多出現風速は $p\left[V_{W}\right]$ の極值に対応する風速として求まり，4.13 m/s 付近であると推定される。さらに，風速 $V_{W}(\mathrm{~m} / \mathrm{s})$ とそ の累積出現率 $p\left[V_{W}\right](\%)$ との関係注 Fig. 2 のと抽りであり，その傾向線は次の式 (2) で表現できる（ $\rho=0.9968 ，$ $\left.\sigma_{\mathrm{E}}=3.14\right)$.

$$
P\left[V_{W}\right]=100\left\{1+\exp \left(6.49-3.21 \sqrt{V_{W}}\right)\right\}^{-1}
$$

また，累積出現率 $P\left[V_{W}\right](\%)$ に対応する風速 $V_{W}\left[P_{V W}\right](\mathrm{m} / \mathrm{s})$ 桜のように導かれる。

$$
V_{W}\left[P_{V W}\right]=\left[\frac{\left.6.49-\ln \left\{100 / P_{V W}\right)-1\right\}}{3.21}\right]^{2}
$$

これらのモデル式から風速の出現頻度に関する次のよらな特性值を知ることができる。

(1) 出現風速の中央值: $V_{W}\left[P_{V W}=50\right]=4.09(\mathrm{~m} / \mathrm{s})$

(2) 出現風速の散布度（ここでは全体の $70 \%$ を占める出現頻度の多い風速区間で示す）： $V_{W}\left[P_{V W}=15\right] \sim$ $V_{W}\left[P_{V W}=85\right]=2.19 \sim 6.56(\mathrm{~m} / \mathrm{s})$

さらに, 必要に応じて (3) 特定風速未満（または以上）の風の出現率および (4) 任意区間風速の出現率が式 (2)を利用して推定できる。

3.2 視程の出現頻度

視程階級別出現頻度の観測結果を各階級の視程中央值に対してプロットすると Fig. 3 のとおりである。視程 出現頻度は階級 7 で最も多く $55.27 \%$ を占め, さらに階級 6 以上では $93.2 \%$ と大部分を占めている。この視 程別観測頻度分布に基つく視程 $D_{V}(\mathrm{~km})$ とその出現率 $p\left[D_{V}\right](\%)$ との相関関係のモデル式は次のとおりである $(\rho=0.9880, \sigma \mathrm{E}=2.90)$ 。

$$
p\left[D_{V}\right]=\left\{0.18 \exp \left(1.84 \sqrt{D_{V}}-0.23 D_{V}\right)\right\}^{2}
$$

ただし， $\quad 0 \leqq D_{V}<50$

関門海峡における任意視程（視程階級）の出現率注式 (3) によって推定され，最多出現視程は $p\left[D_{V}\right]$ の極值 に対応する視程值として求められ，16.0 km 程度であることが推察できる。

次に視程の累積出現率について示したのが Fig. 4 であり，その傾向線は次の式 (4) で表わせる（ $\rho=0.9880 ，$ $\sigma \mathrm{E}=4.85$ )。

$$
P\left[D_{V}\right]=\left[10 /\left\{1+\exp \left(3.80-1.43 \sqrt{D_{V}}\right)\right\}\right]^{2}
$$

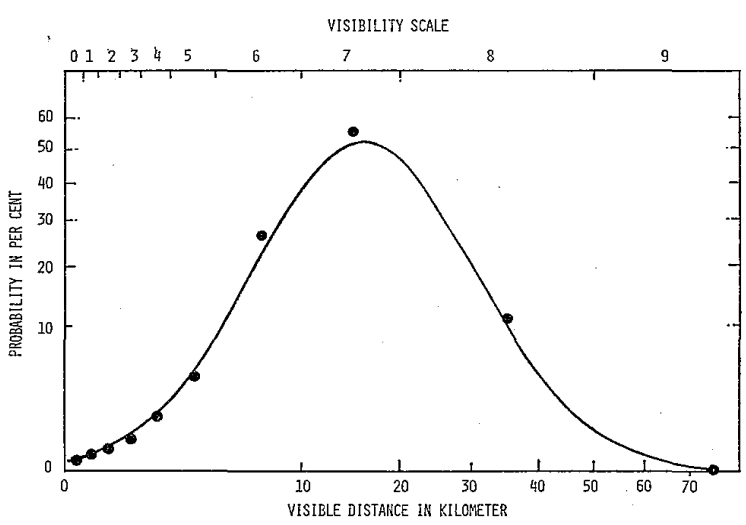

Fig. 3 Frequency distribution of visible distance.

Note; The visible distance in kilometer and the probability in per cent are scaled in the square root values, respectively.

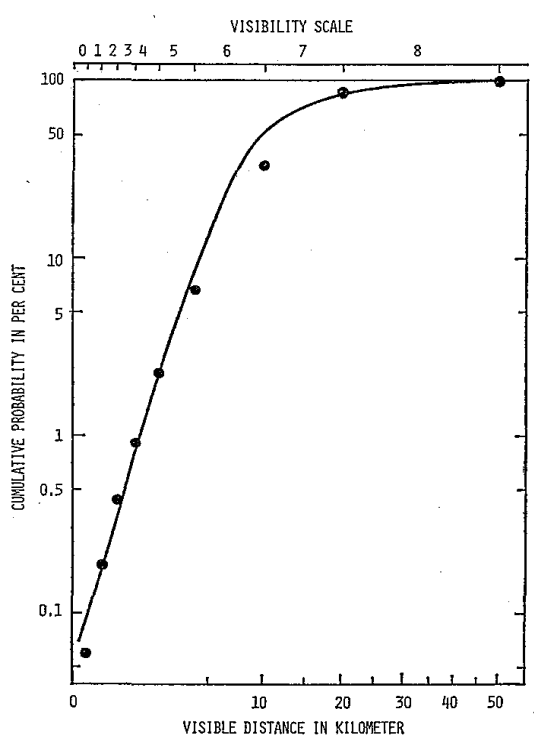

Fig. 4 Cumulative frequency of visible distance.

Note; The visible disttance in kilometer and the cumulative probability in per cent are scaled in the square root and the logarithmic valurs, restpectively. 
また，景積出現率 $P\left[D_{V}\right](\%)$ に対応する視程 $D_{V}\left[P_{D V}\right](\mathrm{km})$ は次式で推定される。

$$
D_{V}\left[P_{D V}\right]=\left[\frac{3.80-\ln \left\{\left(10 / \sqrt{P_{D V}}\right)-1\right\}}{1.43}\right]^{2}
$$

式 (4)および (4') から視程の出現頻度に関する次の特性值が推定される。

(1) 出現視程の中央值: $D_{V}\left[P_{D V}=50\right]=10.72(\mathrm{~km})$

(2) 出現視程の散布度（全体の $70 \%$ を占める出現頻度の多い視程区閒で示す): $D_{V V}\left[P_{D V}=15\right] \sim D_{V}\left[P_{D V}=85\right]$ $=5.46 \sim 19.22(\mathrm{~km})$

このことから閣門海峡で出現する視程の $70 \%$ は，おおよそ $5 \mathrm{~km}$ 19 km であることが推定できる。

(3) 特定の視程未満（または以上）の出現率：例えば視程 $0.5 \mathrm{~km}$ 未満の出現率は， $P\left[D_{V}=0.5\right]=0.34(\%)$ と推算される。

(4) 任意の区関視程の出現率：例えぼ $1 \sim 2 \mathrm{~km}$ の視程出現率は， $P\left[D_{V}=2\right]-P\left[D_{V}=1\right]=1.37(\%)$ と推定で きる。

次に霧 (視程 $<1 \mathrm{~km}$ ) に関して 8 年間の気象観測結果を集約すると，関門海峡における年平均の出現回数は 18.38 回，延出現時間は 49 時間 01 分である。したがって，霧の平均継続時間は 2 時閒 40 分となる。関門海浃 の霧柱 3 月から 6 月にかけて低気圧・前線に伴って発生することが最も多く，次いで 11 月〜 2 月の輻射性のも のが多いようである。また，時刻的には深夜および早朝に発生する霧が比較的多く，霧継続時間は前線性のもの は長く, 輻射性のものは比較的短いことが傾向として認められる。このように霧の継続時間は発生に係わる気象 条件によってかなり異なり，5分程度の短いものから 10 時間以上にも及ぶ長いものまである。しかし，10時間 以上継続する霧の発生は比較的少なく，全体の $4.08 \%$ である。

観測資料に基つく霧継続時間別出現頻度分布は Fig. 5 のとおりで，霧の継続時間 $t$ (時間) と継続時間別霧出 現率 $p[t](\%)$ との相関についてモデル式を導くと次のとおりである $(\rho=0.9805, \sigma \mathrm{E}=2.10) 。$

$$
\left.\begin{array}{rl}
p[t] & =10^{1.58-0.17 t} \\
& =e^{3.63-0.39 t}
\end{array}\right\}
$$

ただし，

$$
0<t<10
$$

Fig. 5 および式 (5) からわかるように，関門海峡の霧は発生から消滅までの時間が短いものが多く，継続時間 の長いもの程その出現率が指数関数的に減小する。

次に継続時間別にみた霧の累積出現率は Fig. 6 のとおりであり, 累積出現率 $P[t](\%)$ 忖次の式 (6) で表現す ることができる $(\rho=0.9869, \sigma \mathrm{E}=3.09) 。$

$$
P[t]=100\{1+\exp (0.41-0.41 t)\}^{-1}
$$

また，糸積出現率 $P[t](\%)$ に対応する継続時間 $t\left[P_{t}\right]$ (時間) は次式のように表わされる。

$$
t\left[P_{t}\right]=1-\frac{\ln \{(100 / P t)-1\}}{0.41}
$$

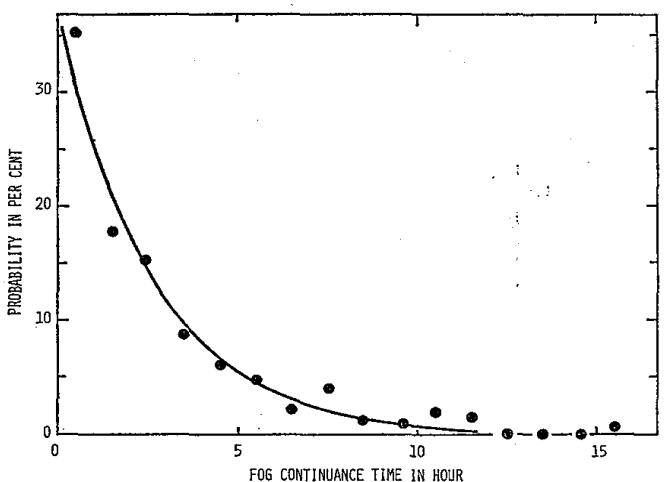

Fig. 5 Frequency distribution of fog continuance time.

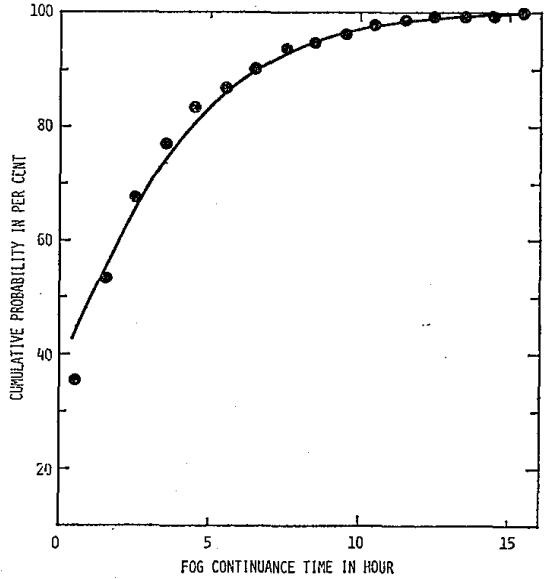

Fig. 6 Cumulative frequency of fog continuance time. 
式 (6) および $\left(6^{\prime}\right)$ から霧継続時間に関して次の特性值が推定できる。

(1) 霧継続時間の中央值: $t\left[P_{t}=50\right]=1.0$ (時間)

(2) 霧継続時間の散布度（全体の $70 \%$ を占める出現頻度の多い霧継続時間の範囲で示す）: $t\left[P_{t}=70\right]=3.07$ (時間)

このことから関門海峡で発生する霧の $70 \%$ 注おおよそ 3 時間以内に消滅することが予想できる。

(3) 霧が発生した場合, 特定時閒内に消滅する確率： 例えば 1.5 時間以内に消滅する確率は, $P[t=1.57=$ $55.11(\%)$

と推定できる。以上のように船舶の安全運航と関係の深い霧継続時間について種々の定量的予测が可能である。

3.3 風速京よび視程が衝突海難に及ぼす影響

関門海峡の衝知海難に及ぼす直接的な気象要素は，風速と視程であると推察される(5)。個々の衝突海難は一般 に操船者・船舶および交通環境等に係わる多くの因子(6)によって偶発する稀現象であり, 風速や視程などの特定 因子と衝突海難との因果関係を定量的に把握することを非常に難しくしている。また，微視的観点にたてば衝突 海難に及ぼす風速・視程の影響は，個々の船舶の大きさ・状態および性能などによっても異なり，きわめて複雑 である。しかし，多くの関係資料に基つく統計的な解析によって巨視的観点から全体を支配する規則性を把握 し，衝突海難に及ぼす風速・視程の影響を評価することは可能である。この評価は全体的・平均的な傾向を示す にとどまるが，安全航行と事故防止対策のための一指針となるら。

ここでは関門海峡通航船の 1 トリップ当り衝突事故率と風速・視程との相関を定式化し，風速・視程が衝突海 難に及ぼす影響について考察した。

\section{3 .1 風速の衝突海難に及ぼす影響}

航行船は風によって圧流および回頭作用をらけ，一般に操縦性能が低下する。特に風が強い場合の低速航行は 保針が難しく操縦不能となることもあるので，関門海峡のような船舶の輻輳する狭唡な水域で洼衝突海難の危険 性が大きいと思われる。

関門海峡で発生した衝突海難について分析し，風速と 1 トリップ当り衝突事故率との関係を Fig. 7 に示す。 さらに風速 $V_{W}(\mathrm{~m} / \mathrm{s})$ と衝突事故率 $p o\left[V_{W}\right]$ との相関について回㷌方程式を求めると次のとおりである（ $\rho=$ $\left.0.9999, \sigma \mathrm{E}=3.61 \times 10^{-5}\right)$ 。

$$
p C\left[V_{W}\right]=\sin ^{2}\left\{3.38-2.19 \sqrt{V_{W}+1}+0.40\left(V_{W}+1\right)\right\}
$$

Fig.7 および式 (7) から衝笑事故率は風速 $6.5 \mathrm{~m} / \mathrm{s}$ 付近で最低 $\left(p c\left[V_{W}=6.5\right]=4.45 \times 10^{-5}\right)$ で, 風速がこれ より大きく（または小さく）なるにしたがって増大僋向をたどることがうかがえる。風速の小さいときは概して 視界不良となりやすい等の関連因子によって衝突事故率が高くなるものと推察される。また, 式 (7) によって各 風速時における推定衝突事故率が求まり, それらの比較対照から風速の衝突海難への影響度を間接的・相対的に

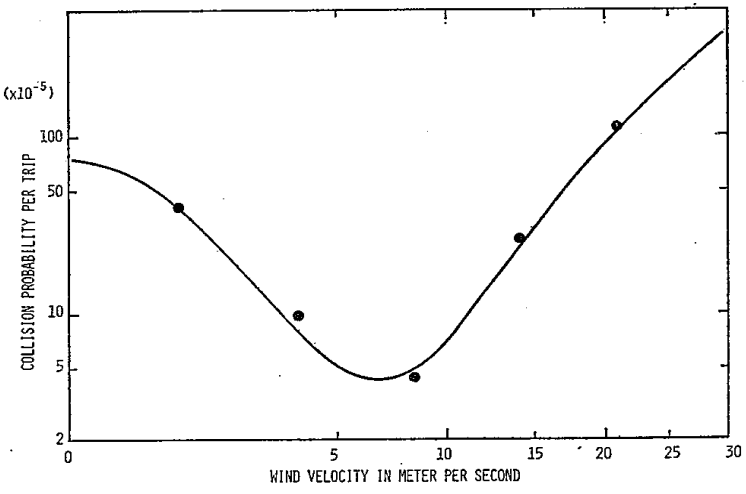

Fig. 7 Relation between collision probability and wind velocity.

Note; The wind velocity in meter per second and the collision probability per trip are scaled in the square root and the logarithmic value, respectively.
Table 1 Degree of the collision risk by wind velocity.

\begin{tabular}{|c|c|c|}
\hline \multirow{2}{*}{$\begin{array}{l}\text { Wind velocity } \\
\qquad\left(V_{W}\right)\end{array}$} & \multicolumn{2}{|c|}{ Collision } \\
\hline & $\begin{array}{l}\text { Probability } \\
\left(p c\left[V_{W}\right]\right)\end{array}$ & $\begin{array}{l}\text { Risk index } \\
\left(I_{r}\left[V_{W}\right]\right)^{*}\end{array}$ \\
\hline $0 \quad(\mathrm{~m} / \mathrm{s})$ & $7.70 \times 10^{-4}$ & 1,119 \\
\hline 4.09 & $6.88 \times 10^{-5}$ & 100 \\
\hline 10.0 & $8.13 \times 10^{-5}$ & 118 \\
\hline 15.0 & $3.17 \times 10^{-4}$ & 461 \\
\hline 20.0 & $9.26 \times 10^{-4}$ & 1,346 \\
\hline 25.0 & $2.08 \times 10^{-3}$ & 3,023 \\
\hline 30.0 & $3.91 \times 10^{-3}$ & 5,683 \\
\hline
\end{tabular}

* $I_{r}\left[V_{W}\right]=\frac{p c\left[V_{W}\right]}{p c\left[V_{W}=4.09\right]} \times 100$ 
評価できる。Table 1 は関門海峡における風速 $4.09 \mathrm{~m} / \mathrm{s}$ (出現風速の中央值)のときの衝突事故率を基準とした 危険指数で，風速の衝突海難に及ぼす影響度を間接的に評価したものである。 $4.09 \mathrm{~m} / \mathrm{s}$ の基準風速時に比べる と, 風速 $10 \mathrm{~m} / \mathrm{s}$ では衝突の危険度は $18 \%$ 增大し, さらに $20 \mathrm{~m} / \mathrm{s}$ の風速環境下では約 13 倍になることが推 察される。このように風速は衝突海難とかなり強い相関関係のあることがうかがえる。

次に風速の及ぼす影響について乗揚海難の場合と比較して考察しよう。関門海峡における乗揚事故率 $P^{\prime}$ と風 速 $V_{W}(\mathrm{~m} / \mathrm{s})$ との相関関係は， $\sin ^{-1} \sqrt{P^{\prime}}=2.58-1.55\left(\sqrt{V_{W}+1}\right)+0.26\left(\sqrt{V_{W}+1}\right)^{2}$ で表わされることを既に報 告(7)した。この式を $P^{\prime}=\sin ^{2}\left\{2.58-1.55 \sqrt{V_{W}+1}+0.26\left(V_{W}+1\right)\right\}$ に変換し式 (7) と対照すると，風の影響パ ターンは衝突海難においても乗揚海難とほぼ同じであることがわかる。

関門海峡の強風は冬期・春期の季節風扝よび低気圧によるものと, 夏期の台風に伴うものが主なもので, 風速 $13 \mathrm{~m} / \mathrm{s}$ 以上が予想される場合には強風注意報が出されている。強風注意報下の衝告危険度は，4.09 m/s の基準 風速時の約 3 倍以上と推定される。したがって，強風注意下の関門海峡の航行については，風に対する特別の警 戒が必要である。

\section{3 .2 視程の衝突海難に及ぼす影響}

レーダの性能が飛躍的に向上し，広く小型船にまで普及した近年においても狭視界時には相変らず衝突海難が 多発する傾向がみられ，視程と衝突海難この間にはかなり高い相関関係があるものと思われる。

関門海陕における視程と 1 トリップ当り衝笑事故率との関係を Fig. 8 に示す。視程 $D_{V}(\mathrm{~km})$ が小さくなるに したがい，衝突事故率 $p c\left[D_{V}\right]$ の増大傾问が認められ両者間の関係は次の式 (8) で表わされる（ $\rho=0.9660 ， \sigma \mathrm{E}$ $\left.=2.28 \times 10^{-4}\right)$ 。

$$
p c\left[D_{V}\right]=\sin ^{2}\left(1.31 D_{V}-0.30\right)
$$

式 (8) から視程による衝突事故率の変動傾问がうかがえ，各視程時における衝突事故率の比較から，視程の衝 突海難に及ぼす影響度について相対的な評価が可能である。Table 2 は関門海峡における視程 $10.72 \mathrm{~km}$ (出現 視程の中央值）のときの衝突事故率を基準にした指数で, 衝突海難に及ぼす視程の影響度を相対評価したもので ある。Table 2 から狭視界時の衝突危険度を具体的に推定することができる。

関門海峡にお污る視程 $D_{V}(\mathrm{~km})$ と乗揚事故率との間には， $\sin ^{-1} \sqrt{P^{\prime}}=1.33 D_{V}^{-0.44}$ で表わされる相関関係の

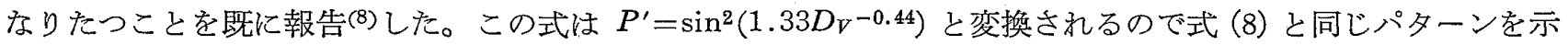
すことがわかる。すなわち，視程活突海難についても乗揚海難の場合とほぼ同様のパターンで影響するとみて よいであろら。

関門地方においては海上視程 $0.5 \mathrm{~km}$ 以下が予想されるとき，濃霧注意報が出されている。この場合は基準視 程 $(10.72 \mathrm{~km})$ 時の 6 倍以上の衝突危険性が潜在すると予想される。したがって, 濃霧注意報下の関門海峡の航 行に関しては事故防止のための十分な配慮と，適切な指導が必要と思われる。

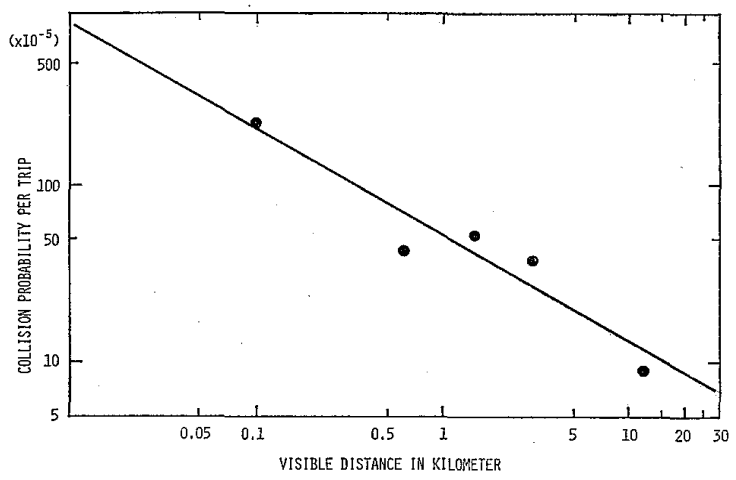

Fig. 8 Relation between collision probability and visible distance.

Note; The visible distance in kilometer and the collision probability per trip are scaled in the logarithmic value, respectively.
Table 2 Degree of the collision risk by visible distance.

\begin{tabular}{c|c|c}
\hline \hline \multirow{2}{*}{$\begin{array}{c}\text { Visible distance } \\
\left(D_{V}\right)\end{array}$} & \multicolumn{2}{|c}{ Collision } \\
\cline { 2 - 3 } & $\begin{array}{c}\text { Probability } \\
\left(p_{C}\left[D_{V}\right]\right)\end{array}$ & $\begin{array}{c}\text { Risk index } \\
\left(I_{r}\left[D_{V}\right]\right)^{*}\end{array}$ \\
\hline $0.1(\mathrm{~km})$ & $2.08 \times 10^{-3}$ & 1,651 \\
0.5 & $7.92 \times 10^{-4}$ & 629 \\
1.0 & $5.23 \times 10^{-4}$ & 415 \\
2.0 & $3.45 \times 10^{-4}$ & 274 \\
4.0 & $2.28 \times 10^{-4}$ & 181 \\
8.0 & $1.50 \times 10^{-4}$ & 119 \\
10.72 & $1.26 \times 10^{-4}$ & 100 \\
\hline
\end{tabular}

$* I_{r}\left[D_{V}\right]=\frac{p_{C}\left[D_{V}\right]}{p_{C}\left[D_{V}=10.72\right]} \times 100$ 


\subsection{3 衝突海難に及ぼす風速および視程影響度の比較}

・衝突海難に及ぼす強風の影響は，広い水域においてはほとん ど問題にならないであろう。しかし，3.3.1 からわかるように 関門海峡では強風時の衝灾危険度がかなり高くなる傾向があ る。強風の衝突海難への影響度について視程のそれと比較対照 するため，式 (7) および (8) から $p c\left[D_{V}\right]=p c\left[V_{W}\right]$ として衝 突事故率が同值となる風速と視程の対応関係を Fig. 9 に示す。 Fig. 9 加風速 $13 \mathrm{~m} / \mathrm{s}$ の強風は衝突危険度に関して視程 $5 \mathrm{~km}$ の視程環境と同等であり， $17 \mathrm{~m} / \mathrm{s}$ の強風は視程 $1 \mathrm{~km}$ の狭視 界とほぼ同様の衝突危険性をはらんでいると推察される。関門 海峡では風速 $15 \mathrm{~m} / \mathrm{s}$ 以上の場合は視程 $2 \mathrm{~km}$ 未満の狭視界時 とほぼ同等の衝突危険性のあることを認識して, 船舶交通の安 全をはかるための配慮がなさる心゙きである。

\section{4.むす び}

関門海峡における船舶交通の安全対策に資することを目標

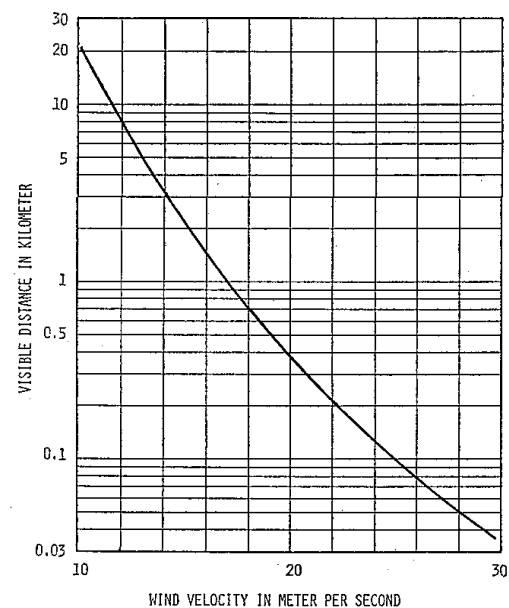

Fig. 9 Correspondence of wind velocity to visible distance in respect of the influence on collision.

に, 風速・視程の出現頻度および風・視程が衝突海難に及ぼす影響について現象の定式化を試み, 衝突海難の発 生と強風・狭視界との間にかなり高い相関関係のあることを定量的に確かめた。また，資料解析によって導かれ た各モデル式は，それぞれの現象についての特性把握を容易にし，必要に応じて比較的よい近似度で所要值の推 算に利用できる。したがって，風速や視程の出現頻度に関する予測や衝突危険度についての客観的事前評価が可 能であり，風や視程の気象要素をレベルとする航行安全対策の資料整備がより円滑・簢便に行なえるであろら。 しかし，モデル式によって得られる推定值は，あくまで全般的な傾向を示す平均的な指標である。したがって， 個々の船舶の安全運航に法各船舶の状態と，気象状況全般についての総合的な情勢判断が加味されなければなら ない。

終わりに資料の収集に関して種々の便宜を与えられた第七管区海上保安本部，および下関此方気象台の関係各 位に深莧の謝意を表します。

参考 文 献

（1）日本航海学会：関門航路における海難防止対策，(1963).

（2）福山コンサルタント：関門海峡の船舶航跡調査報告書，（1966）.

（3）第四港湾建設局：関門航路における通航船舶調查報告書一一早鞆瀬戸地区一，（1967）.

（4）第四港湾建設局：関門航路に抆ける通航船舶調查報告書一大瀬戸地区一，（1968）.

（5）神鳥 昭：関門海峡に括ける衝突海難と気象との関係，日本航海学会論文集第 47 号， pp. 79 91, (1972).

（6）神鳥 昭：海上交通事故, 航海第 46 号, pp. 39 59, (1975).

（7）神鳥 昭：関門海峡における㐘揚海難と気象との関係，日本航海論文集第 51 号，p. 3 (1974).

（8） 前掲 (7), p. 6 .

\section{質 疑 応 答}

藤井弥平 1） データ数と対象年数。

2）風速が小さいとき危険度が高いのは風と視程の関係によるものではないか。

神鳥 昭 1) 解析に使用したデータ数と対象年数は次のとおりです。

風速および視程各 8,760 ( 3 年間)

霧

147 ( 8 年間)

通航船舶数

16,350（ 4 年間のうちの 18 日間） 


\section{衝突海難隻数 $\quad 302$ (8 年間)}

2）御指摘のと招り風速の小さいときに衝突の危険度が高いのは，狭視界との関連によるものと推察されま す。

松本吉春 1） 視程はどのようにして観測されましたか。

2）風速が弱いとき海難が多いのは風速と視程の関倸が大きいのも原因と思われるので個々に解析するよりも 両者の関連において考えるべきと思うがどうですか。

3）風向と視程の関係はどうなっているか。

神鳥 昭 1）視程についてのデータは下関地方気象台の観測データを使用しました。このデータは目視観測 によるものです。

2）御説のとおり弱風時の衝突海難は視程との関連があると思われますので，衝乫事故率・風速および視程の 3 变数間の多元相関で処理した方が実態の把握にはより好都合と考えられます。今回は乗揚海難の解析結果（既 報）との比較上单相関で処理しましたが，今後は御指摘のような解析方法をとりいれたいと思います。

3）関門海陕の風向と視程（特に狭視界）との間には関連があるように思います。狭視界となりやすいのは無 風状態と東寄りの風のときです。因みに 3 年間の毎日 3 時間ごとの観測データについて，風向（4象限に区分） と狭視界 $(<4 \mathrm{~km})$ との関係をみますと次のとおりです。

\begin{tabular}{|c|c|c|c|c|c|c|}
\hline 風 & $\mathrm{NW} \sim \mathrm{NE}$ & $\mathrm{NE} \sim \mathrm{SE}$ & $\mathrm{SE} \sim \mathrm{SW}$ & $\mathrm{SW} \sim \mathrm{NW}$ & Calm & 計 \\
\hline 3 年閒の出現回数 (A) & 1,873 & 4,077 & 340 & 2,370 & 100 & 760 \\
\hline 視界出現回数 & 59 & 369 & 22 & 124 & 18 & \\
\hline$(\mathrm{B} / \mathrm{A}) \times 100$ & 3.15 & 9.05 & 6.47 & 5.23 & 18.00 & \\
\hline
\end{tabular}

